\title{
A juvenile Early Carboniferous (Viséan) coelacanth from Rösenbeck (Rhenish Mountains, Germany) with derived postcranial characters
}

\author{
Florian Witzmann*, Markus Dorka and Dieter Korn \\ Museum für Naturkunde Berlin, Invalidenstraße 43, 10115 Berlin, Germany. \\ E-mail: florian.witzmann@mfn-berlin.de; markus.dorka@mfn-berlin.de; dieter.korn@mfn-berlin.de
}

\begin{abstract}
Received 8 November 2009

Accepted 29 January 2010

Published 3 August 2010

\section{Key Words}

Sarcopterygii

Brilon Anticline

lobed fins

Palaeozoic

postcranium

A small coelacanth specimen of Viséan age from a newly described locality near Rösenbeck at the northern margin of the Rhenish Mountains (North Rhine-Westphalia, Germany) is described. The head and pectoral girdle are not preserved, however, the specimen can be distinguished from all other known Carboniferous coelacanths by derived characters of the articulated postcranial skeleton. Derived characters include: (1) The slender first and second dorsal fins that carry only seven to eight and six fin rays, respectively. (2) Both the pelvic and anal fin have a broad base and are unusually weakly lobed. (3) The fin rays of the second dorsal fin are much more robust than those of the first dorsal fin. (4) The second dorsal and anal fins are longer than the first dorsal and pelvic fins. The Rösenbeck coelacanth is interpreted as a juvenile specimen, since the basal plates that support the fins are not ossified.
\end{abstract}

\section{Introduction}

Coelacanth fishes are a rare component of faunal assemblages in Carboniferous strata of Germany, first reported by Aldinger (1931) and Keller (1934). The Carboniferous coelacanths known so far from Germany encompass the following taxa:

(1) Rhabdoderma elegans (Newberry, 1856) ('Coelacanthus watsoni') from the 'Namurian' to 'Westphalian C' of the Ruhr Region (Aldinger 1931; Keller 1934; Forey 1981) and from the 'Namurian A $\left(E_{1}\right)$ ' of Rosenhof near Niederhemer, northern Rhenish Mountains, Germany (Horn 1960, pl. 5, fig. 4). This taxon was also documented in the 'Namurian' to 'Westphalian C' of the British Isles, northern France, Belgium, and the Netherlands, in the 'Westphalian D' of Linton, Ohio, and the 'Stephanian' of the Ukraine (Forey 1981, 1991).

(2) Rhabdoderma tingleyense (Davis, 1884) ('Coelacanthus mucronatus') was found in the 'Westphalian $\mathrm{A}-\mathrm{C}$ ' of the Ruhr Region, Germany, as well as in the 'Westphalian' of the British Isles, northern
France, Belgium, and the Netherlands (Keller 1934; Forey 1991).

(3) Rhabdoderma stensioei (Aldinger, 1931) ('Coelacanthus stensiöi') from the 'Namurian A ( $\left.\mathrm{E}_{1}\right)$ ' of Rosenhof near Niederhemer (Aldinger 1931; Keller 1934; Cloutier \& Candilier 1995). R. stensioei was also identified from strata of the latest 'Viséan' to 'Namurian A' of Belgium (Demanet 1938, 1941, 1943; Cloutier \& Candilier 1995).

(4) Coelacanthus sp. was described by Aldinger (1931) from the 'Namurian A $\left(E_{1}\right)$ ' of Rosenhof near Niederhemer.

(5) Additional coelacanths are known from non-German Carboniferous strata of Western and Middle Europe, including Rhabdoderma ?aldingeri MoyThomas, 1937 from the 'Namurian A' of Wales, Belgium and Northern France (Moy-Thomas 1937; Cloutier \& Forey 1991; Cloutier \& Candilier 1995), and R. huxleyi (Traquair, 1881) from the 'Viséan' of Scotland (Cloutier \& Forey 1991) and probably the 'Namurian A' from Belgium and northern France (Cloutier \& Candilier 1995).

\footnotetext{
* Corresponding author
} 
In this paper, we describe the postcranial skeleton of an Early Carboniferous coelacanth from a locality near Rösenbeck (northern Rhenish Mountains, Germany) and discuss its taxonomic affinities and ontogenetic age.

\section{Geographic and geological framework}

The fossil coelacanth described in this article comes from the easternmost outcrop of two large productive limestone quarries, where Devonian reef platform limestones ('Massenkalk') are exploited. The quarry is situated $1.3 \mathrm{~km}$ south-west of Madfeld and $2.4 \mathrm{~km}$ northeast of Rösenbeck at the northern margin of the Rhenish Mountains $\left(51.4246^{\circ} \mathrm{N} ; 8.7081^{\circ}\right.$ E) (Fig. 1).
The Rösenbeck locality is positioned on the Brilon Anticline, of which the centre is mainly formed by the massive Devonian reef platform limestones. These limestones contain numerous dykes (Fig. 2), which were filled with sediments of different geological age (Clausen \& Leuteritz 1984). Dykes with Carboniferous sediments were described from Rösenbeck by Bär (1968), and are well-exposed at various places within the quarry.

A clear succession of Carboniferous sedimentary rocks was obviously never exposed in the quarry; however, the Devonian limestones are, at some places, discordantly overlain by crinoidal limestones of Tournaisian age containing a mixed conodont fauna with early Late Devonian to Tournaisian elements (pers.
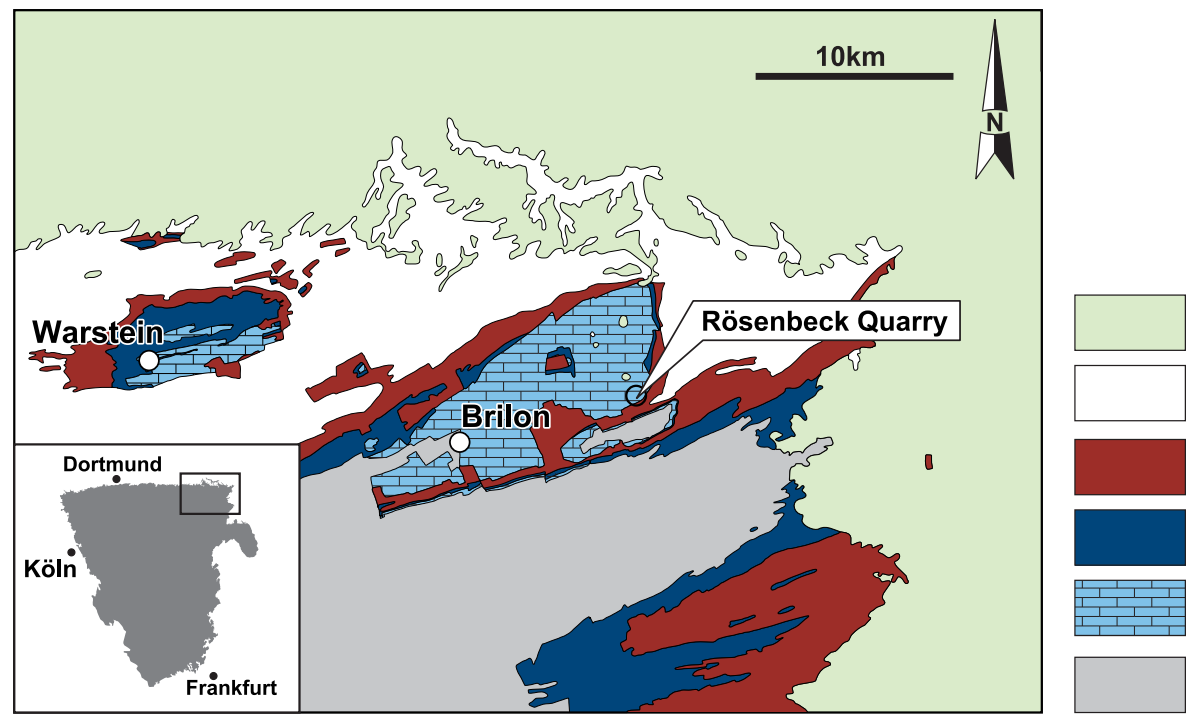

Permian to Cenozoic

Serpukhovian, Baschkirian

Tournaisian, Viséan

Late Devonian

massive limestones (M. Dev.)

Ordovician to Middle Devonian

Figure 1. Geological map of the north-western Rhenish Mountains with the Rösenbeck locality.

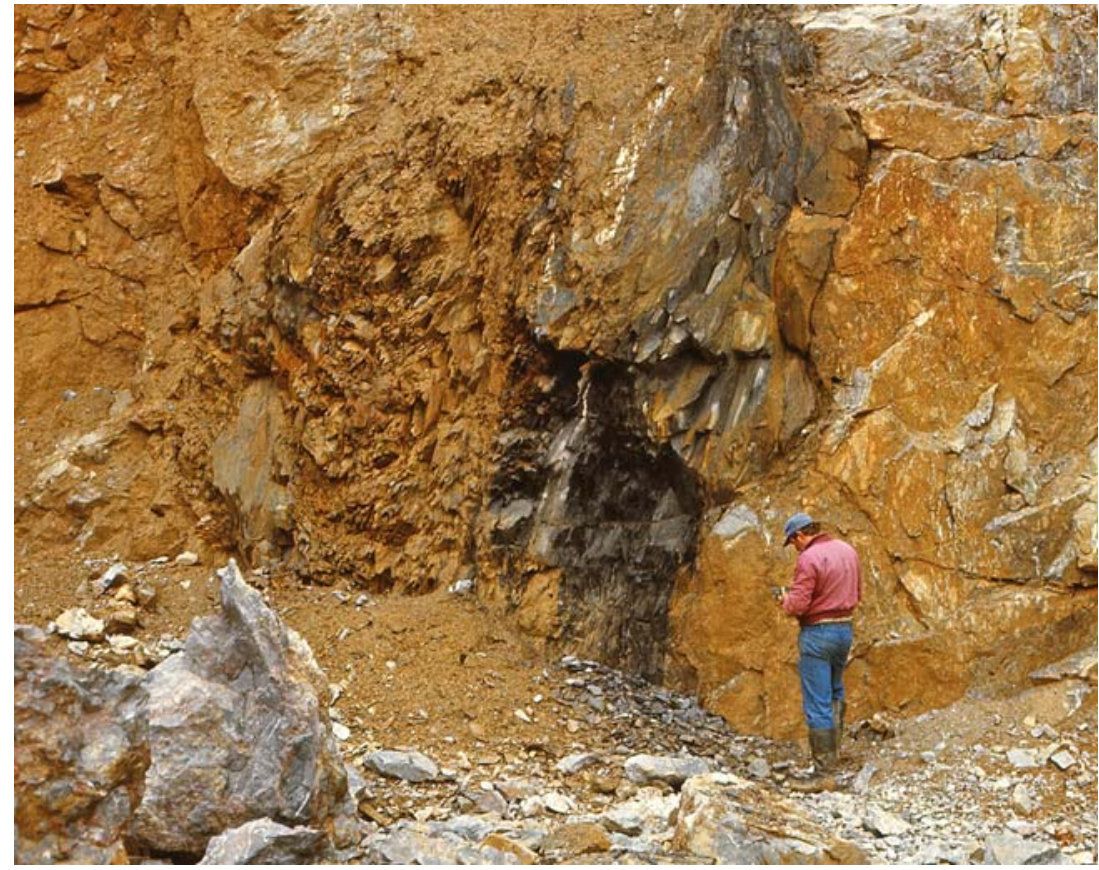

Figure 2. The outcrop of Late Viséan black shales (bleached in the upper portion) of about $3.5 \mathrm{~m}$ thickness in a neptunian dyke in Middle Devonian massive limestones in the Rösenbeck quarry; photograph June, 1978. 
comm. 1992 Dieter Stoppel, Hannover) or by micritic limestones containing the Viséan index ammonoid Goniatites crenistria (Phillips, 1836). The presence of G. crenistria in this limestone refers to the best Early Carboniferous index horizon of the Rhenish Mountains (Nicolaus 1963; Mestermann 1998; Korn 2008) and allows at least a rough correlation of the overlying shales.

The shales above the $G$. crenistria Limestone yielded few fossils, including the coelacanth specimen described here. The specimen was found in loose material without any accompanying index fossils, however the specimen can be probably stratigraphically correlated by the find of a specimen of Cousteauceras costatum (Ruprecht, 1937) on another slab of similar lithology and a coprolite-like structure on the coelacanth slab, resembling a weathered phosphoritic nodule. The ammonoid belongs to the latest Viséan Caenolyroceras chalicum Zone (Korn \& Horn 1997), and the probable coprolite also suggests a latest Viséan age (unpublished data from neighbouring localities). The presence of Cousteauceras costatum indicates that the coelacanth from Rösenbeck lived in a marine environment.

\section{Material}

MB.f.12377a, b: Coelacanth postcranium with counterpart of the caudal fin preserved on a slab of strongly bleeched, decalcified shale. The specimen is stored in the Museum für Naturkunde Berlin.

\section{Description of specimen MB.f.12377}

\section{Preservation and morphological overview}

MB.f.12377 is an articulated postcranial skeleton that is $85 \mathrm{~mm}$ in length. The anteriormost part of the trunk and most parts of the supplementary lobe of the caudal fin are not preserved on the slab, whereas the two dorsal fins, the pelvic and the anal fins are well visible (Figs 3-4). The endochondral basal plates that support the dorsal fins and the pectoral and anal fins are not preserved. An ossified lung, which is frequently preserved in fossil coelacanths, is not visible in this specimen. The preservation of the various parts of the skeleton differs within the specimen. The fins are discernible by the imprints of the internal faces of the fin ray segments. The fin rays of all paired and unpaired fins are segmented distally and do not show any signs of bifurcation. Elements of the axial skeleton are preserved as casts or indicated by distinct moulds. Some of these moulds contain a shiny substance, which could be either bone tissue or diagenetic secondary crystallization. The substance does not show a distinct pattern of distribution and does not fill any of the moulds completely.

The anterior part of the specimen is poorly preserved. The course of the anterior neural arches is not continuous, and large areas do not show any skeletal remains at all. The latter could be due to the diagenesis of the sediment, because the layering in the corresponding part of the slab is disturbed. It is not possible to relate this disturbance to a particular diagenetic process, but the absence of any kind of burrows makes bioturbation unlikely. There are three groups of fossil elements in this problematic area of the slab, which cannot be unambiguously identified. First, there are several casts and imprints of curved crests at the anteroventral part of the skeleton that might represent scale ornament. Second, rod-shaped elements at the anterior end of the slab are interpreted as fin rays of the pectoral fin, however, it is not clear if they indicate the original position of this fin in the skeleton. Third, these possible fin rays are overlain by the imprint of a large element of ill-defined outline, which might belong to the skull or pectoral girdle. The large black mould above the posterior end of the first dorsal fin might have contained a phosphoritic nodule (possibly a completely weathered coprolite) and does not belong to the fossil fish.

\section{Axial skeleton and caudal fin}

Axial skeleton. Following the definition provided by Forey (1998, p. 213), the anteriormost caudal vertebra has a haemal spine that supports a radial (or fused interhaemal plus ventral radial sensu Arratia et al. (2001), see below) but does not carry a fin ray. There are at least 32 abdominal vertebrae (identified by neural arches in the trunk region), but the vertebrae of the anterior trunk region are not preserved. The anteriormost haemal arch is located ventral to the 18th or 19th preserved precaudal neural arch, so that the posteriormost 12 or 13 precaudal vertebrae bear haemal arches and spines. Judging from the number of neural and haemal arches as well as from the fin rays, approximately 19 caudal vertebrae are present. No vertebral centra and ribs can be discerned in the axial skeleton. Each neural arch is a bifurcated structure that continues dorsally in a long, slender neural spine. The arches are rather delicate in the portion of the vertebral column preserved anterior to the pelvic fin. More posterior, at the level of the first dorsal fin, the arches become more robust and the length of the spines increases gradually towards the caudal fin. The neural spines are longest and widest in the anterior portion of the caudal fin and decrease in size towards the end of the tail. In the trunk region, the neural spines are straight, whereas they are slightly anterodorsally concave in the anterior caudal region.

Caudal fin. In coelacanths, the caudal fin is diphycercal and possesses a supplementary lobe (Forey 1991). This lobe in the new specimen, however, is poorly preserved and is only indicated by few remnants of fin rays, so that nothing can be said about its outline and length. The epichordal (dorsal) lobe of the caudal fin has approximately $17-18$, and the hypochordal (ventral) lobe has approximately 18 lepidotrichia or fin rays. In the 


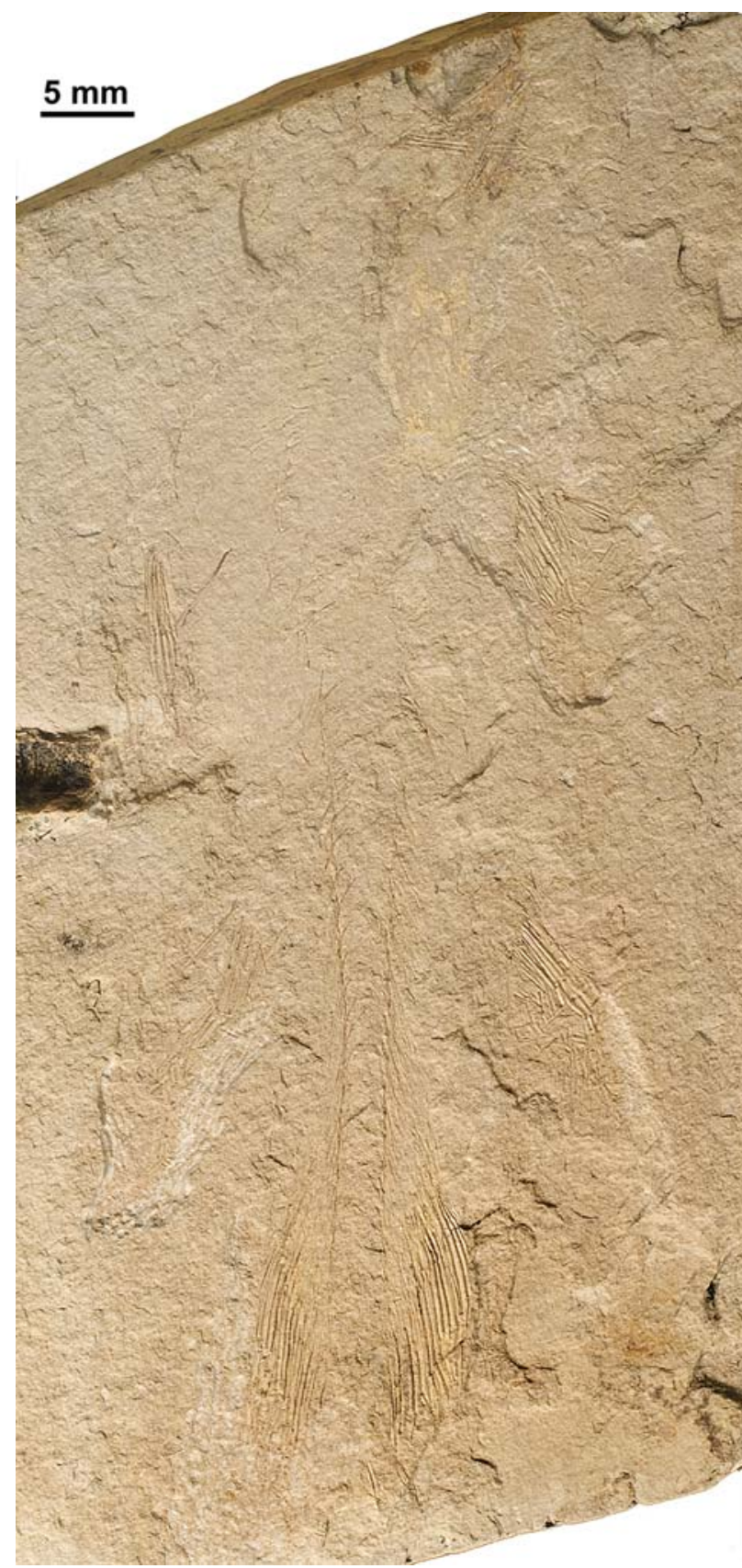

Figure 3. Photograph of specimen MB.f.12377a.

hypochordal lobe, robust haemal arches are present that possess long haemal spines and correspond in outline to the respective neural arches plus spines of the epichordal lobe. Distal to the neural and haemal spines of the caudal fin, there is one row of endoskeletal element in each case. These single endoskeletal elements in coelacanths are commonly refered to as dorsal and ventral radials (e.g. Forey 1998). However, Arratia et al. (2001) interpreted the single elements distal to the neural spines as consisting of fused supraneural plus dorsal radial and the elements distal to the haemal spines as fused interhaemal plus ventral radial. The distally located fin rays, which are segmented distally, correspond in number to the endoskeletal elements and do not bifurcate.

\section{Dorsal fins}

The anterior margin of the first dorsal fin is located posterior to the hind margin of the pelvic fin. It is, however, possible that the first dorsal fin was displaced postmortem, because its distance from the vertebral column is unusually large and the fin seems to be slightly rotated. It carries seven or eight slender, segmented fin rays. The proximal segments of the three anteriormost fin rays are curved in a posterodorsal direction. The segments become progressively smaller distally and the distal ends of the fin rays are tapering. The proximal ends of the fin rays are aligned in a straight row indicating that the first dorsal fin was not lobed, a common feature in coelacanths. A long element between the vertebral column and the posteroventral end of the first dorsal fin might represent another proximal fin ray segment.

The second dorsal fin lies opposite to the anal fin and is approximately $30 \%$ longer than the first dorsal fin. It consists of six fin rays, the anteriormost of which is restricted to its unsegmented part and is thus distinctly shorter than the following ones. It is tapering distally. The proximal segments of the fin rays appear more robust than those of the first dorsal fin; the distal segments, however, become short and slender. Because of the low number and the great length of the fin rays, the second dorsal fin has a slender outline. The proximal ends of the fin rays form a ventrally concave line; if this is not an artifact of preservation, it indicates that the fin was only slightly lobed.

\section{Pectoral and pelvic fins and anal fin}

Length and shape of the pectoral fin cannot be reconstructed. It is represented by three rather long and parallel, unsegmented fin rays that are located anterior to the preserved part of the vertebral column.

The pelvic fin is situated posteroventral to the pectoral fin and is composed of approximately 12 fin rays. The anteriormost three or four rays are poorly preserved but seem to be more slender and shorter than the following ones. The proximal fin margin is slightly concave dorsally, indicating that the pelvic fin was probably only slightly lobed.

The anal fin is clearly broader and more robust than the pelvic fin. It carries 11 or 12 broad fin rays, plus three or four short, slender rays at the anterior and posterior margin of the fin, respectively. Similar to the other fins, the fin ray segments become more slender, shorter and tapered at their distal ends.

\section{Remains of uncertain affinity}

Several short crests are scattered over an area anterior to the pelvic fin and ventral to the anterior end of the vertebral column (Fig. 4). The crests are slender and most of them are curved. They might represent remains of the scale ornament (i.e. elongate tubercles). However, edges of scales cannot be recognized. 


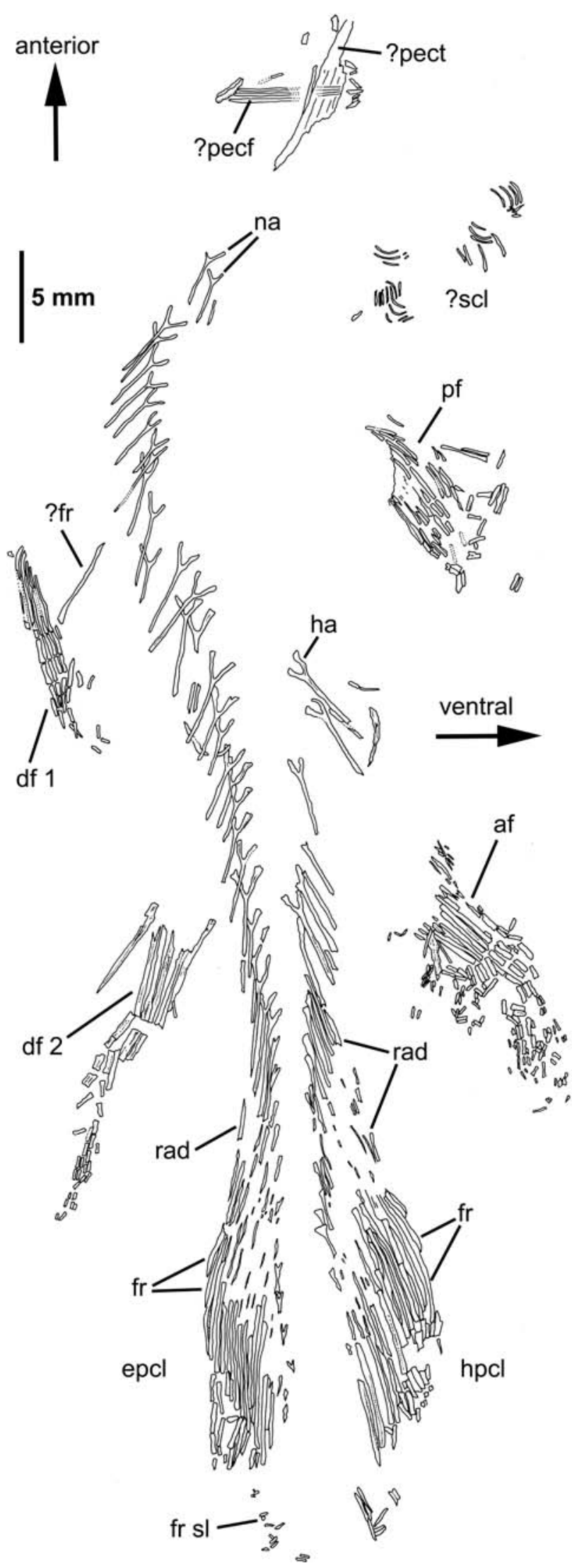

Figure 4. Drawing of coelacanth specimen MB.f.12377a. Abbreviations: af - anal fin; df - dorsal fin; epcl - epicaudal lobe; fr - fin ray; fr sl - fin rays of supplementary lobe; ha - haemal arch; hpcl - hypocaudal lobe; na - neural arch; pecf - pectoral fin; pect - pectoral girdle; pf - pelvic fin; rad - radial; scl - scales.

\section{Discussion}

\section{Comparisons and taxonomic assignment of MB.f.12377}

Specimen MB.f.12377 can unambiguously be identified as a coelacanth by the following characters (see Forey 1991 and Cloutier 1996): the caudal fin is diphicercal and consists of outwardly equal main lobes on the dorsal and ventral side of the vertebral column, and the supplementary lobe is present; absence of distal radials at the first and second dorsal fins; a first dorsal fin located more anteriorly than in other piscine sarcopterygians; second dorsal and anal fins that are obviously (slightly) lobed; vertebral ossifications restricted to fork-shaped neural and haemal arches that are fused with long spines.

It is possible to distinguish MB.f.12377 from other coelacanths by its postcranial anatomy, in spite of the fact that the skull is not preserved. Postcranial morphology is sufficiently well known for the contemporary genus Rhabdoderma for comparison. No apomorphic character is shared with the postcranium of species of Rhabdoderma and the following comparison shows that it cannot be assigned to one of the existing late Palaeozoic taxa. A genus or species is not erected in the absence of the skull, however, because it is this region, which generally bears most of the taxonomically relevant characters.

Relative length of second dorsal and anal fins. A remarkable character in postcranial anatomy of MB.f.12377 is the greater length of the second dorsal and anal fins compared to the first dorsal and pelvic fins. Furthermore, the fin rays of the second dorsal and anal fins are proximally more robust than those of first dorsal and pelvic fins. This character does not appear in Rhabdoderma elegans (Forey 1981), R. tingleyense (Davis 1884) and R. huxleyi (Traquair 1881); the character is unknown in R. stensioei (Aldinger 1931; Demanet 1938, 1941, 1943) and Coelacanthus sp. from the Ruhr Region (Aldinger 1931). Only the basal Devonian actinistian Miguashaia bureaui Schultze, 1973 (Cloutier 1996, fig. 1) and Rhabdoderma exiguum Eastman, 1902 (Forey 1981, fig. 12; Balon 1991, fig. 4), have a second dorsal fin that is longer than the first dorsal fin, plus an anal fin that is longer than the pelvic fin. However, the dorsal unpaired fins of the latter consist of a much greater number of fin rays, whereas the pelvic fin carries a much smaller number of fin rays than the corresponding fins in MB.f.12377 (see above). At this point, it shall be mentioned that $R$. exiguum possibly encompasses more than one species. Forey (1998) reported two coelacanth specimens from the Mazon Creek fauna that can be distinguished by their higher counts of vertebrae (64 and 70) and caudal fin rays $(20 / 20$ and 20/18) from the other specimens from Mazon Creek (with 55-58 vertebrae and a caudal fin ray count of 15-16/16; see below). The second dorsal corresponds in size to the first dorsal fin or is smaller in the early Carboniferous coelacanths from the Bear 
Gulch Limestone from Montana, USA (Caridosuctor populosum, Polyosteorhynchus simplex, Hadronector donbairdi and Allenypterus montanus Lund \& Lund, 1984) (Lund \& Lund 1984, 1985). The first and second dorsal fins have a similar length in the Late Permian coelacanths Coelacanthus granulatus Moy-Thomas, 1937 and Changxingia aspratilis Wang \& Liu, 1981 (Moy-Thomas 1937; Wang \& Liu 1981).

Dorsal fins. Both the first and the second dorsal fins of MB.f.12377 are slender and carry seven to eight and six fin rays, respectively. These fins probably appeared as acute triangles rather than rounded in outline. In Rhabdoderma elegans, the first and second dorsal fins are composed of a greater number of fin rays (10 and 14-15 fin rays, respectively), and this holds true also for $R$. tingleyense (15 and 16 fin rays, respectively), $R$. huxleyi (9-10 and 10-11 fin rays, respectively), and R. exiguum (12-13 and 15 fin rays, respectively) (Forey 1981, fig. 12; Forey 1998).

Pelvic and anal fins. In MB.f.12377, the pelvic and the anal fin (carrying 12 and around 15 fin rays, respectively) are probably distinctly broader than the dorsal fins, and rounded in outline. In contrast to other coelacanths, these fins have a broad base and are unusually weakly lobed. A pelvic fin with a similar low degree of lobation was illustrated for a small individual of Rhabdoderma exiguum (Forey 1981, fig. 12), although in this specimen the pelvic fin carries only six fin rays.

Caudal fin. In the caudal fin of MB.f.12377, there are approximately 17-18 fin rays in the dorsal lobe and approximately 18 fin rays in the ventral lobe. This number differs from Rhabdoderma elegans (12-13 fin rays in both lobes), $R$. tingleyense (21-23 fin rays in both lobes), and the two questionable specimens of R. exiguum mentioned by Forey (1998) (22/20 and 20/18, respectively). MB.f.12377 is more similar to $R$. huxleyi (16-17 fin rays in both lobes) and $R$. exiguum (15-16/ 16) (Forey 1981, 1998).

Pectoral fin. Poor preservation of the pectoral fin in MB.f.12377 precludes detailed comparison with other coelacanths. However, the preserved long, unsegmented fin rays differ from the pectoral fin rays of Rhabdoderma huxleyi, that are segmented right to their bases and constitute a distinctive character of this species (Forey 1981).

\section{Ontogenetic status of MB.f.12377}

MB.f.12377 is a fairly small individual in comparison with the adults of many other coelacanths including the contemporary Rhabdoderma. We regard this specimen as a juvenile rather than a small-growing adult for the following reasons. First, the endoskeletal basal plates of the unpaired and paired fins are not visible and can therefore be interpreted as entirely cartilaginous in the living animal. The basal plates of fins obviously start to ossify comparatively late in ontogeny of coelacanths. The ossification sequence of the postcranium is partially documented in the early growth stages of Rhabdoderma exiguum, in which neural and haemal arches, fin rays and their endoskeletal supports are yet ossified, while the basal plates of the fins are not (Schultze 1980, fig. 5). The basal plates also cannot be identified in the embryos of the Late Jurassic Undina penicillata Münster, 1834 from Solnhofen; however, they can be indentified in the adults, and were therefore interpreted as cartilaginous in the living embryos by Watson (1927). Second, the weak lobation of the anal fin might support the interpretation of MB.f.12377 as a juvenile. In the basal coelacanth Miguashaia bureaui, the anal fin is not lobed in the juvenile stage, whereas lobation is developed in the adult specimens (Schultze 1973; Cloutier 1996). Small juveniles of Rhabdoderma exiguum, however, do possess clearly lobed anal fins (Schultze 1980, fig. 5), and this is also the case in the embryos of $U n$ dina penicillata (Watson 1927). As indicated by small specimens of Rhabdoderma exiguum (Schultze 1972, 1980), Axelrodichthys sp. (Brito \& Martill 1999) and Latimeria chalumnae Smith, 1939 (Anthony \& Robineau 1976), a typical character of juvenile coelacanths is the supplementary lobe of the caudal fin that is proportionally distinctly longer than in adults. Unfortunately, the supplemetary lobe of the caudal fin in MB.f.12377 is not adequately preserved to determine its length.

If our interpretation of the juvenile status of MB.f.12377 is correct, the elongated second dorsal and anal fins could be ontogenetic and not taxonomic varation. Unfortunately, fossil ontogenies of coelacanths are very rare, and comparisons are therefore restricted to Rhabdoderma exiguum, Undina penicillata, Axelrodichthys sp. and the extant Latimeria chalumnae. Although long second dorsal and anal fins were illustrated for small growth stages of Rhabdoderma exiguum (Schultze 1980, fig. 5), no information is available concerning this character in later ontogenetic stages of this species. In the embryos of Undina penicillata, the length of the first dorsal corresponds to that of the second dorsal fin, and the anal fin appears to be smaller than the second dorsal fin (Watson 1927, pl. 2). This relationship is retained in adult specimens (personal observations). Similarly, second dorsal and anal fins are not enlarged with respect to first dorsal and pelvic fins in juveniles of Axelrodichthys sp. (Brito \& Martill 1999, fig. 1) and the extant Latimeria chalumnae (Anthony \& Robineau 1976, fig. 1; Balon et al. 1988, fig. 11). We thus assume that the proportionally large second dorsal and anal fins represent a derived character of MB.f.12377 rather than a juvenile character, shared only with Rhabdoderma exiguum.

\section{Indications for the mode of life}

The unusual relative length of the second dorsal and anal fins might give some hints concerning the mode of life of this animal. In coelacanth evolution there is an increase in the lobation of the second dorsal and the anal fins (Forey 1991, 1998). Increased lobation 
was demonstrated to be associated with an emphasis of these fins to produce the locomotory thrust during slow locomotion. In Latimeria chalumnae, these distinctly lobed fins constitute a flexible blade; they are primarily employed in forward and backward propulsion and dominate in acceleration and curve swimming (Fricke \& Hissmann 1992). In MB.f.12377, the second dorsal and anal fins are apparently only slightly lobed, indicating that they were probably stiffer than fins with a stronger lobation. The proportionally greater length and robustness of the fin rays suggest that these fins might have contributed to a larger degree to acceleration than the more flexible and lobed second dorsal and anal fins of other coelacanths.

\section{Conclusions}

The new specimen of a coelacanth from latest Viséan shales of Rösenbeck is regarded as a juvenile because the basal plates that support the fins are not visible and can therefore be interpreted as cartilaginous in the living animal. The two dorsal fins, the pelvic and anal fins are well preserved, therefore, the lack of basal plates is not an artifact of preservation. The Rösenbeck coelacanth cannot be assigned to an already existing species or genus because it shares no apomorphies with them. However, it shows three autapomorphic characters in the postcranial anatomy: (1) the first and second dorsal fins consist of only seven to eight and six fin rays, respectively, and are therefore very slender in outline; (2) the pelvic and anal fins are both broad-based and exceptionally weakly-lobed; (3) the fin rays of the second dorsal fin are much more robust than those of the first dorsal fin. Additionally, the second dorsal and anal fins are longer than the first dorsal and pelvic fins in the new specimen and in Rhabdoderma exiguum; however, the second dorsal fin of $R$. exiguum consists of many more fin rays than that of the Rösenbeck coelacanth. Although the postcranial characters listed above are derived, we do not regard them as sufficient for defining a new species or genus since the skull, which is unfortunately not preserved, generally bears most of the taxonomically relevant characters in coelacanths.

\section{Acknowledgements}

The reviews of Martin Rücklin (Bristol, UK) and Rainer Schoch (Stuttgart) helped greatly to improve the manuscript. Kerin Claeson (Austin, Texas) is acknowledged for many helpful comments on the text.

\section{References}

Aldinger, H. 1931. Über karbonische Fische aus Westfalen. - Paläontologische Zeitschrift 13: 186-201.

Anthony, J. \& Robineau, D. 1976. Sur quelques charactères juvéniles de Latimeria chalumnae Smith (Pisces, Crossopterygii Coelacanthidae). - Comptes rendus des séances de l'Académie des Sciences D 283: 1739-1742.
Arratia, G., Schultze, H.-P. \& Casciotta, J. 2001. Vertebral column and associated elements in dipnoans and comparison with other fishes: development and homology. - Journal of Morphology 250: $101-172$.

Balon, E. K. 1991. Probable evolution of the coelacanth's reproductive style: lecithotrophy and orally feeding embryos in cichlid fishes and in Latimeria chalumnae. - Environmental Biology of Fishes 32: 249-265.

Balon, E. K., Bruton, M. N. \& Fricke, H. 1988. A fiftieth anniversary reflection on the living coelacanth, Latimeria chalumnae: some new interpretations of its natural history and conservation status. Environmental Biology of Fishes 23: 241-280.

Bär, P. 1968. Die ober-devonisch/unter-karbonische Schichtlücke über dem Massenkalk des Briloner und Messinghäuser Sattels (OstSauerland). - Neues Jahrbuch für Geologie und Paläontologie, Abhandlungen 131 (3): 263-288.

Brito, P. M. \& Martill, D. M. 1999. Discovery of a juvenile coelacanth in the Lower Cretaceous, Crato Formation, Northeastern Brazil. Cybium 23: 311-314.

Clausen, C.-D. \& Leuteritz, K. 1984. Erläuterungen zu Blatt 4516 Warstein. Geologische Karte von Nordrhrein-Westfalen 1:25000, Erläuterungen, 4516 Warstein: pp. 1-155.

Cloutier, R. 1996. The primitive actinistian Miguashaia bureaui Schultze (Sarcopterygii). In Schultze, H.-P. \& Cloutier, R. (eds). Devonian fishes and plants of Miguasha, Quebec, Canada. Verlag Dr. Friedrich Pfeil, München: pp. 227-247.

Cloutier, R. \& Candilier, A.-M. 1995. Palaeozoic vertebrates of Northern France and Belgium: Part III - Sarcopterygii (Devonian to Carboniferous). - Géobios, Manuscrit Spécial 19: 335-341.

Cloutier, R. \& Forey, P. 1991. Diversity of extinct and living actinistian fishes (Sarcopterygii). - Environmental Biology of Fishes 32: 59-74.

Demanet, F. 1938. La faune des couches de passage du Dinantien au Namurien dans le synclinorium de Dinant. - Mémoires du Musée Royal d'Histoire Naturelle de Belgique 84: 1-201.

Demanet, F. 1941. Faune et stratigraphie de l'Étage Namurien de la Belgique. Mémoires du Musée Royal d'Histoire Naturelle de Belgique 97: 1-327.

Demanet, F. 1943. Les horizons marins du Westphalien de la Belgique et leurs faunes. - Mémoires du Musée Royal d'Histoire Naturelle de Belgique 101: 11-66.

Davis, J. W. 1884. On a new species of Coelacanthus (C. tingleyensis) from the Yorkshire Cannel Coal. - Transactions of the Linnean Society of London 2: 427-433.

Eastman, C. R. 1902. The Carboniferous fish fauna of Mazon Creek, Illinois. - Journal of Geology 10: 535-541.

Forey, P. 1981. The coelacanth Rhabdoderma in the Carboniferous of the British Isles. -Palaeontology 24: 203-229.

Forey, P. 1991. Latimeria chalumnae and its pedigree. - Environmental Biology of Fishes 32: 75-97.

Forey, P. 1998. History of coelacanth fishes. Chapman \& Hall, London. Fricke, H. \& Hissmann, K. 1992. Locomotion, fin coordination and body form of the living coelacanth Latimeria chalumnae. - Environmental Biology of Fishes 34: 329-356.

Horn, M. 1960. Die Zone des Eumorphoceras pseudobilingue im Sauerland. - Fortschritte in der Geologie von Rheinland und Westfalen 3 (1): 303-342.

Keller, G. 1934. Fischreste aus dem Oberkarbon des Ruhrgebiets. Glückauf. Berg- und Hüttenmännische Zeitschrift 40: 913-917.

Korn, D. 2008. Early Carboniferous (Mississippian) calciturbidites in the northern Rhenish Mountains (Germany). - Geological Journal 43 (2-3): 151-173.

Korn, D. \& Horn, K. 1997. The Late Viséan (Early Carboniferous) goniatite stratigraphy in the South Portuguese Zone, a comparison with the Rhenish Massif. - Newsletters on Stratigraphy 35 (2): 97-113.

Lund, R. \& Lund, W. L. 1984. New genera and species of coelacanths from the Bear Gulch Limestone (Lower Carboniferous) of Montana (U.S.A.) - Géobios 17: 237-244. 
Lund, R. \& Lund, W. L. 1985. Coelacanths from the Bear Gulch Limestone (Namurian) of Montana and the evolution of the Coelacanthiformes. - Bulletin of the Carnegie Museum of Natural History 25: 1-74.

Mestermann, B. 1998. Mikrofazies, Paläogeographie und Eventgenese des crenistria-Horizontes (Obervisé, Rhenohercynicum). - Kölner Forum für Geologie und Paläontologie 2: 1-77.

Moy-Thomas, J.A. 1937. The Carboniferous coelacanth fishes of Great Britain and Ireland. - Proceedings of the Zoological Society of London B 3: 383-415.

Münster, G. Graf zu. 1834. Mitteilungen an Professor Bronn gerichtet. - Neues Jahrbuch für Mineralogie, Geognosie, Geologie und Petrefakten-Kunde 1834: 538-542.

Newberry, J. S. 1856. Descriptions of several genera and species of fossil fish from Carboniferous strata of Ohio. - Proceedings of the Academy of Natural Sciences of Philadelphia 8: 96-100.

Nicolaus, H.-J. 1963. Zur Stratigraphie und Fauna der crenistria-Zone im Kulm des Rheinischen Schiefergebirges. - Beihefte zum Geologischen Jahrbuch 53: 1-246.

Phillips, J. 1836. Illustrations of the geology of Yorkshire; or a description of the strata and organic remains; accompanied by a geological map, sections, and diagrams, and figures of the fossils. Part II. The Mountain Limestone District. J. Murray, London.
Ruprecht, L. 1937. Die Biostratigraphie des obersten Kulm im Sauerlande. - Jahrbuch der Preußischen Geologischen Landesanstalt 57 (for 1936): 238-283.

Schultze, H.-P. 1972. Early growth stages in coelacanth fishes. - Nature New Biololgy 236: 90-91.

Schultze, H.-P. 1973. Crossopterygier mit heterozerker Schwanzflosse aus dem Oberdevon Kanadas, nebst einer Beschreibung von Onychodontida-Resten aus dem Mitteldevon Spaniens und aus dem Karbon der USA. - Palaeontographica A 143: 188208.

Schultze, H.-P. 1980. Eier legende und lebend gebärende Quastenflosser. - Natur und Museum 110: 101-108.

Smith, J. L. B. 1939. A living fish of Mesozoic type. - Nature 143: 455-456.

Traquair, R. H. 1881. Notice of new fish remains from the Blackband Ironstone of Borough Lee, near Edinburgh. - Geological Magazine 1881: 491-494.

Wang, N. \& Liu, H. 1981. Coelacanth fishes from the marine Permian of Zhejiang, South China. - Vertebrata PalAsiatica 19: 305-312. [in Chinese with English summary]

Watson, D. M. S. 1927. The reproduction of the coelacanth fish, Undina. - Proceedings of the Zoological Society of London 1927 453-457. 